\title{
Social and environmental problems of religious deviation: from critical methodology to practice
}

\author{
Vadim Rosenfeld ${ }^{1}$ and Rida Zekrist $^{1 *}$ \\ ${ }^{1}$ Bashkir state pedagogical University named after M. Akmulla, 450000, st. October Revolution, 3a, \\ Ufa, Russia
}

\begin{abstract}
The question of the relationship between religion and power in the post-secular era, as well as the problem of social inequality of new religious movements with traditional religions, is a real challenge, and not only to social sciences. The relevance of the topic reveals the inevitability of analyzing the phenomenon of the revival of religiosity, in which complex processes of lack of trust, the interconnection of systemic development and religious security take place. The search for solutions to the problem requires an understanding of historical experience, including an appeal to sociophilosophical analysis. The article presents a reflection on the principles in solving problems related to the prevention of the influence of destructive religious groups. The proposed example of a socio-philosophical analysis of the problem under study, as one of several interrelationships between religion, power, education and humanism, is carried out through the concepts of "spiritual security", "religious security", "education", "critical thinking" and "confessional stability". In conclusion, a thesis is proposed that allows a multi-level and deeper discussion of the problem with the ability to formulate real solutions and their conditions.
\end{abstract}

\section{Introduction}

At present, the complication of society is not so much due to an increase in the number of subsystems, but due to an increase in the number and a profound change in the quality of the relationships between them. This complication is reflected in state-confessional and interconfessional relations.

Therefore, it is so important that any assessment of future dramatic shocks should have a critical, complex character and be formulated in the context of common knowledge and systemic relations "person - society - person". Critical, that is, clear thinking will allow you to find an answer to the origin of the concept of "religious deviation", suggest the direction of assessment and help answer the question of whom it will serve or already serve.

Critical reflection and evaluation are all the more necessary, since quality is determined by the number of negative, not positive, characteristics. In the case of the well-known concepts and ideas about religious deviation, including later attempts to implement it, we can say that almost all of them have common features and are implemented through fear mongering and the use of advanced technologies, digital, media and auxiliary methods.

* Corresponding author: art-profi-1@,yandex.ru 
The problem of the aggressive influence (missionary work) of deviant religious cults is one of the most painful aspects of Russian reality.

The phenomenon of the revival of religiosity, characteristic of the whole world in the post-secular era in Russia, has a special content. Speaking about contemporary Russian reality, it is necessary to recognize the religious factor as one of the most influential. Thus, the last 120 years have brought tremendous upheavals in the social and political life of Russia, accompanied by changes in the spiritual sphere, the tragedy of the destruction of hundreds of thousands of people and the suffering of millions in connection with their religious faith. And today, having completed the circle, and in a new capacity, the issues of freedom of conscience and freedom of religion remain important and sometimes painful for both Russia and its citizens.

In the post-Soviet space, the post-secular period is by no means limited to the rehabilitation of the constitutional freedom of worshiping the needs of the population. A modern citizen of the Russian Federation is constantly confronted with the concept of "religion" in the media, social activities, economics and business, healthcare, etc. After a certain period of life in the 90s. The 20th century witnessed a conscious revival of the dominant of "traditional religions", spreading its influence over many spheres of social relations. The declarative congruence of the "religion-state" tandem makes one speak almost of the restoration of the principles of Justinian's sixth short story "On the Symphony." The priority of "traditional religions", to which Orthodoxy, Islam, Buddhism and Judaism are commonly referred to, took the form of an unofficial doctrine of "spiritual values" that claims to fill the ideological space.

The narrative about the cultural and historical mission of "traditional religions" for a long time dominated not only in the sphere of interfaith relations, but also in state-confessional relations, which had a number of negative consequences. The cultural and historical significance of "traditional religions" is undeniable, but this realization sometimes leads to the denial of equality with other religious movements, which could not but leave an imprint on the latter's awareness of their "secondary role" in the system of state relations. This, in turn, shaped the nature and form of their religious activity - aggressiveness, secrecy, promiscuity in the forms of involving new adherents. In the Russian Federation, according to religious scholars, at least four hundred cults and religious communities are operating, the activities of which, for these reasons, have a number of destructive forms. In the last decade, this problem has often been the subject of discussion at various venues. This moves it from the category of taboo to the state of discussion, which in itself is a well-known progress, although the issues of prevention, methodology and practice of the latter are rather declarative in nature. Only the events of the last year forced the administrative structures to resort to a number of specific measures.

\section{Materials and methods}

This discussion raises the following research question: Is it possible to develop a methodology that allows not only to study the phenomena of religious deviation in Russian reality, but also to form and implement effective methods of their prevention?

When constructing the structure of the study, we were guided by two important circumstances: the first is that the development of religion and social phenomena are typical manifestations of self-organization, the second is that both religious studies and the theory of self-organization of complex systems, by definition, are transdisciplinary sciences, have methodological mutual adequacy and reflect the equal level of complexity of the subjects of study. Focusing on the problem of methodology as a whole, VP Bransky [1] rightly asserts that "the theory of self-organization based on selection provides an exhaustive explanation of all ... phenomenological signs of development (complexity, diversity, adaptation)". 
Researcher R. Zekrist [2] writes that understanding the nonlinearity of socio-religious dynamics leads to the idea of the possibility - at certain stages - of maximizing instability, an unusual acceleration of the development of processes. The mechanism of such development is based on a volumetric nonlinear positive feedback. Moreover, it may turn out to be significant for each point (sample) of the socio-religious environment. The emergence and presence of a new sample in the social field can lead to a sharp increase in the rate of its own production. At the same time, the very local change in the state of the socio-religious environment affects the action of a nonlinear source in a given place, for example, the expansion of religious deviation. Volumetric nonlinear positive feedback, therefore, means an accelerated self-sustaining growth of this innovation throughout the space of the socioreligious environment, leading to a weakening of other religious patterns.

The influence of small perturbations, generally speaking, is different depending on three factors:

- from the stage of development of the structure, process, regime with aggravation (the regime can be at a long quasi-stationary stage);

- from the location of the disturbance (whether it falls into the central part of the socioreligious structure or to its periphery);

- on the measure of the complexity of the structure.

A small (subthreshold) perturbation does not play any role at all, it is completely forgotten if, at the quasi-stationary stage, it falls on the periphery of a complex structure.

Why is the methodology of critical regimes with exacerbation adequate for understanding the evolution of religious organizations prone to instability and crises? The model of regimes with aggravation is methodologically rather complicated, because it contains within itself the possibility of switching to a regime of the opposite nature. The nonlinearity itself, if it is strong enough, determines the existence of two regions: a sharpening region (where the initial disturbance increases) and a damping region (where the initial disturbance vanishes, is leveled).... nonlinearity leads to the existence of a region of peaking and a region of damping of the process, as well as a mechanism for transferring from one state to another due to always existing fluctuations .... The methodology of critical regimes with exacerbation allows us to understand the nature of the processes of superfast, avalanche-like, explosive growth in the socio-religious environment, the nature of evolutionary crises, catastrophic processes of the collapse of religious organizations and catastrophes by switching opposite in meaning and complementary critical regimes [3].

The practical result of the introduction of a systemic methodology, in our opinion, will be the development and introduction of a course on religious security, combining legal, educational, cultural and spiritual aspects, and aimed exclusively at preventing the influence of destructive religious groups.

\section{Results}

Speaking about the problem of the influence of religious cults, a very significant detail must not be overlooked. Many of the religious movements are not "pure religion" in the classical sense of the word. According to T. Fitzgerald [4], "religion" is only a half-category, the other half is "secular". The production of the "secular" is made possible by the production of "religion" and vice versa. Having experienced in a certain time period the influence of social, political, ethnic, commercial, destructive and quasi-theological postulates, post-secular religiosity is, to a certain extent, their compilation. Accordingly, it cannot but fulfill the functions of a latent or explicit carrier of these ideas. Accordingly, the majority of modern religious movements are active in social, political, economic and other social activities. The activity is aimed, first of all, at the transmission of ideas into society, sometimes very far from the religious ideal. 
We proceed from the understanding that the task of protecting religious principles in modern society seems impossible. The prestige of churches, the attendance of parishes are falling, all spheres of society are being modernized. The only strategy of believers against the "disappearance of religion" is resistance. Direct resistance strategies are rarely successful. It was the tactics of "resistance" that were chosen in their activities by the movement "Against the digital concentration camp" by O. Chetverikova, "Ivan-tea" by E. Zhgutova, "People's Commissar" by A. Schwabauer and others.

The situation became extremely aggravated during the spread of coronavirus infection in 2020. Researcher R. Lunkin [5,6] believes that if "a part of the Christian world (the Vatican and the liberal Protestant churches) unconditionally submitted to the requirements of the state for the sake of European solidarity, which has become a kind of religion for the churches of Europe, then a number of Orthodox religious movements took a position of sharp confrontation (as illustrated in the table). A number of the actual ministers of the Russian Orthodox Church, such as Sergiy Romanov and others, joined them. The so-called "covid theology" developed, consisting of anti-vaccination, anti-digital and other fundamentalist phenomena, which are, in fact, part of the anti-globalization movement.

Table 1. Assessment by representatives of groups of the dynamics of social tension in Russia as a whole, in regions and settlements (in\%) [7].

\begin{tabular}{|c|c|c|c|c|c|c|}
\hline \multicolumn{2}{|c|}{ Issocialtensionincreasing ... } & 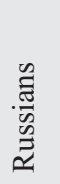 & $\begin{array}{l}\text { ô } \\
\frac{0}{0} \\
\stackrel{0}{0} \\
0\end{array}$ & $\begin{array}{l}\vec{D} \\
\stackrel{D}{D} \\
\\
\Xi \\
\Xi\end{array}$ & 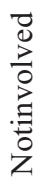 & $\begin{array}{l}\frac{n}{0} \\
\frac{n}{2} \\
\frac{\pi}{*}\end{array}$ \\
\hline \multirow{5}{*}{ 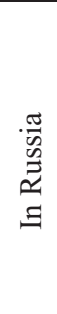 } & Voltagedropssignificantly & 6 & 5 & 5 & 5 & 5 \\
\hline & The voltage drops a little & 15 & 15 & 17 & 15 & 10 \\
\hline & The tension rises a little & 37 & 37 & 29 & 38 & 41 \\
\hline & Voltagerisessubstantially & 21 & 21 & 25 & 21 & 25 \\
\hline & The situation is the same as it was before & 22 & 22 & 24 & 21 & 20 \\
\hline \multirow{5}{*}{$\begin{array}{l}0 \\
0 \\
\Xi \\
0 \\
0 \\
.0 \\
\Xi \\
\Xi\end{array}$} & Voltagedropssignificantly & 5 & 6 & 6 & 6 & 4 \\
\hline & The voltage drops a little & 14 & 14 & 18 & 13 & 12 \\
\hline & The tension rises a little & 35 & 35 & 32 & 36 & 41 \\
\hline & Voltagerisessubstantially & 14 & 15 & 12 & 15 & 17 \\
\hline & The situation is the same as it was before & 32 & 30 & 32 & 30 & 27 \\
\hline \multirow{5}{*}{ 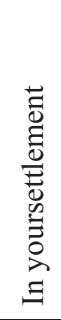 } & Voltagedropssignificantly & 6 & 6 & 5 & 6 & 5 \\
\hline & The voltage drops a little & 14 & 14 & 17 & 13 & 12 \\
\hline & The tension rises a little & 31 & 33 & 30 & 33 & 37 \\
\hline & Voltagerisessubstantially & 13 & 14 & 12 & 15 & 16 \\
\hline & The situation is the same as it was before & 36 & 33 & 36 & 33 & 30 \\
\hline
\end{tabular}

All this provoked harsh retaliatory measures against the most radical religious figures. 
As noted by Rossiyskaya Gazeta, in 2016 the Supreme Court of the Russian Federation recognized the decision of the Moscow City Court to liquidate the Church of Scientology in Moscow as legal.

On the website "Interfax-Religion" we find that on April 20, 2017, by the decision of the Supreme Court of the Russian Federation, the activities of the religious organization "The Administrative Center of Jehovah's Witnesses in Russia" and all its 395 regional branches were declared extremist and banned on the territory of Russia. On August 17, 2017, the Ministry of Justice of the Russian Federation included the "Administrative Center of Jehovah's Witnesses in Russia" and its 395 local religious organizations in the list of organizations banned in Russia.

Rossiyskaya Gazeta writes that on September 22, 2020, the founder and head of the Church of the Last Testament, S. A. Torop (Vissarion), was detained by the FSB of Russia.

The Investigative Committee of the Russian Federation, on December 29, 2020, the former cleric of the Russian Orthodox Church Sergiy (Nikolai) Romanov, known for his protest statements, was detained and arrested.

In the Urals, the former schema-monk Sergius was detained, who seized the monastery (TASS, 12/29/2020).

In November 2020, RamilyaSaitova, a representative of the occult-religious movement, known for her pro-Turkish and nationalist position, was detained and arrested in Ufa.It is necessary to be aware that this option has a number of weaknesses, suffice it to name:

- traditionally weak for Russia legal and expert study of the issue.

- an openly opportunistic political component.

- a limited resource of a forceful solution to the problem - it is impossible to imprison all representatives of a major religious cult.

- in connection with the growth of protest sentiments in Russia, repressions on a religious basis contribute to a positive image of the object of repression.

Thus, it is necessary to draw a conclusion about the very limited effectiveness of a forceful solution to the problem. Are there other ways possible?

It is necessary to mention alternative methods, which, despite many years of testing, are still insufficiently developed.

There is an opinion that the culture of traditional religions, carried out in a number of regions under the rather vague concept of "spiritual security" or "elimination of religious illiteracy", can serve as a kind of panacea for destructive influence. But one should be aware that the elimination of religious illiteracy means religious education. That is, in essence, a sermon. Are traditional religions ready to launch a religious literacy program today? With a methodology, a unified concept, a body of teachers, teaching aids? Willthisexperiencebesuccessful?

Now people in different spheres can choose different forms of religiosity. In defending their religious values, traditional religions must take into account that they do not have a monopoly on faith. In such conditions, without changing the line of behavior, in the near future we may witness, at least, the expansion of the number of traditional religions or the elimination of this concept as such. We can witness a natural secularization - as defined by the religious scholar Dmitry Uzlaner [8], the process by which religious thinking, practice and religious institutions lose their social significance.

The boundaries of traditional religions are extremely blurred. Such a phenomenon as pseudo-Orthodoxy and pseudo-Islam has become a reality. Accordingly, sects and psychocults disguised as traditional religions will certainly take control of a part of the educational process. And since they are more mobile, more organized, and methods of counteraction have not been developed, this part will be very significant. Moreover, the more preferences and benefits traditional religions receive, the more cults will seek to work under this guise. The 
formation of New Religious Movements uses technology that is far ahead of Sunday school methodology.

If we talk about a purely secular methodology for prevention, it is necessary to take into account that the "declarative" approach prevails here as well. But, the declaration is not yet a solution to the problem.

The preliminary but necessary measures are far from being resolved:

- the need for a scientific study of social and psychological factors of the spiritual security of youth. This is complemented by the undeveloped effects of the social influence of modern society on the worldview, socio-political and spiritual-moral attitudes of the younger generation. We have an extremely vague idea of the target audience, which should become the object of preventive measures.

- undeveloped tools for prevention. With a sufficiently high level of research into the methods of religious radicals and extremists, the "contra" events are sporadic and technologically not well developed.

- in connection with the latter, the absence of intelligible attempts at confrontation in the main missionary field of religious radicalism - information.

As we know, information is a commodity as intangible as energy, but almost the most widespread in all spheres of human activity. In the modern world, an information avalanche of all kinds of religious propaganda falls on a person every day, and without observing psychological, pedagogical and legal norms.

The danger is caused by the following factors:

- lack of regulations governing the activities of NRMs (new religious movements)

- the lack of sufficient numbers of religious scholars in the regions who are able to distinguish religion from a sect, or a psychocult.

- the absence of any concept in the field of information counteraction to the influence of destructive religious groups.

In modern Russian society, the potential of the press and other information media is traditionally underestimated as a factor in the formation of social values and social ideals.

Regardless of our desire, mass communication has become a monolithic part of the economy, politics, and culture of Russian society, but it acts more spontaneously than controlled. Outside of influence and control - revolutionary technologies of mass communication, first of all, the Internet. Prohibitive measures proposed to it cannot, in any way, replace methodologically objective educational technologies. The consequences of this situation on the issue of the spread of radical religious phenomena are reflected in the most negative way. Cults use the principle of mass communication, realize the effect of constant presence in the life of their victim, and their influence on order is stronger. The very principle of their work is built on communication, with the obligatory principle of feedback. It should be taken into account that the user's confidence in information from a social network is immeasurably higher than in information from federal or republican media. According to B. Russell [9], the transfer of information can occur only if this information interests you or if it is assumed that it can influence the behavior of people.

The preventive material sent to the masses is a priori designed for the traditional system of values, taking into account the dogmas of traditional confessions, without preliminary research of the audience's current value orientations.

One of the methods of reducing confessional tension is considered to be a kind of "raising the cultural level of the population" in general, in particular by increasing the cultural disciplines. Apart from the methodological utopian nature of this project (an increase in the teaching load in schools), it is worth taking into account the following.

Cults, as a rule, work not with intellect, but with a complex of primitive superstitions, at the level of basic human needs. But this is what makes their tactics a win-win. And superstitions, to one degree or another, are subject to almost EVERYTHING, regardless of 
social and intellectual status. Accordingly, you can increase the level and number of cultural disciplines as much as you like, but this will weakly protect people from the influence of deviant religious cults. It is well known that scientists, politicians and businessmen fell under sectarian influence along with housewives. And the level of knowledge and culture is not a panacea for involvement in a sect and a psychocult, especially in the latter. Accordingly, lower the bar and talk about religious and not spiritual security. And this is not just terminological disagreement.

Can we now rely on the inner world and spiritual experience of Russians when they are absolutely religiously disoriented? An extremely unpleasant paradox - almost 30 years of complete religious freedom and even encouragement of religiosity have led to almost universal religious illiteracy of the population. What is religious illiteracy? This is the level of everyday occultism. And it is the widespread spread of occultism that is the real danger. Not religiosity, but a complex of primitive superstitions, which is a nutritious broth for the spread of destructive cults.

According to experts, "religious security" is a complex of pedagogical, religious studies, psychological norms aimed at developingreligious immunity in young people to the uncontrolled influence of destructive cults that generate ethnic conflicts.

\section{Discussion}

This section briefly discusses the above data and summarizes the results in light of the research question.

Thus, the study by Larry Stapleton, Dawton Marques, Tejan Thakar [10] "Systemic Control, Cultural Values and Religious Institutions An Assessment of Semi-Automatic Human Values Systems Analysis in Religious Institutional Diagnostics" shows that there is some consistency between the values of leaders and priorities members of organizations that could create potential problems. For example, fig. Table 2 shows that participants generally gave higher priority to safety in their lives as a guiding principle than leaders.

Table 2. Comparison of Ten Value Domainsin the Religious Community: Leadership versus Membership.

\begin{tabular}{|l|l|l|l|}
\hline Domain Values & Congregation & Leadership & $\begin{array}{l}\text { Difference } \\
\text { (Leadership }- \\
\text { Congregation) }\end{array}$ \\
\hline Conformity & $5.39(12,1 \%)$ & $5.73(12,3 \%)$ & 0.34 \\
\hline Tradition & $4.25(9,5 \%)$ & $4.51(9,7 \%)$ & 0.26 \\
\hline Benevolence & $5.52(12,4 \%)$ & $5.85(12,5 \%)$ & 0.32 \\
\hline Universalism & $4.79(10,7)$ & $4.92(10,6 \%)$ & 0.12 \\
\hline Self-direction & $4.45(10 \%)$ & $4.58(9,8 \%)$ & 0.13 \\
\hline Stimulation & $3.41(7,6 \%)$ & $3.33(7,1 \%)$ & -0.08 \\
\hline Hedonism & $4.33(9,7 \%)$ & $3.85(8,3 \%)$ & -0.48 \\
\hline Achievement & $4.49(10 \%)$ & $4.91(10,5 \%)$ & 0.41 \\
\hline Power & $3.09(6,9 \%)$ & $3.61(7,8 \%)$ & 0.52 \\
\hline Security & $4.99(11,2 \%)$ & $5.34(11,4 \%)$ & 0.34 \\
\hline
\end{tabular}

This research, in fact, leads us to a conflicting understanding of how "religious security" is understood for the religious adepts themselves?

Since there is a range of opinions among leaders and members of organizations, then, following the systemic critical methodology, it can be assumed that such a situation systematically exists in social organizations of different types. Moreover, the external religious studies analysis on the issue of religious security will clearly diverge from the intrasystemic processes of the religious organization itself. 
Above, we said that the formation of New Religious Movements uses technologies that are far ahead of the methods of Sunday schools. In this regard, the position of Thomas Frissen [11] in the article "The Internet, a great radicalizer? Exploring the relationship between the search for extremist materials on the Internet and the cognitive radicalization of young people. Anecdotal evidence suggests that extremist content on the Internet plays a critical role in radicalization processes. However, due to the structural lack of empirical evidence in the current literature, it remains unclear whether and to what extent extremist materials on the Internet radicalize. Step-by-step linear regression analysis and a structural equation model confirmed the researcher's hypothesis that the process of cognitive radicalization is a complex step-by-step trajectory from an active search for extremist materials to sympathy for violent political behavior.

Also noteworthy for us is the analysis of the role of the Internet in religious education presented by the researcher Saeid Zargham i Hamrah [12], both from the standpoint of theoretical and practical conclusions on the use of the Internet in religious education. To this end, religious education is viewed by the author as a process in which a student's faith, commitment and religious, social and moral behavior are formed and developed in an explanatory, critical and passionate procedure and using criteria for assessing the accuracy or inaccuracy of beliefs, obligations and actions. Applied research methods - hermeneutic phenomenology with qualitative content analysis. Based on the research results, the ontological characteristics of virtual experience in relation to personal experience are as follows: distancing of virtual experience; disruption of spatial and temporal boundaries in virtual experience; development of virtual relationships; and increasing the availability of technological information. Then the bottlenecks or horizons of the mentioned ontological characteristics in the development of the mentioned characteristics for religious education are analyzed. The Internet, for example, has removed restrictions imposed by place and time, as well as the hierarchical power of the teacher in transmitting information in the process of religious education; it provided a more expanded and free context for the exchange of religious ideas and beliefs through the proliferation of virtual relationships. On the other hand, since there is no full bodily presence and sensational experience in virtual education, the development of aspects such as intrinsic motivation, faith, intrinsic experience, intrinsic commitment and action faces some disadvantages.

David Webber et al. [13] in a survey on ideologies that justify political violence identifies various tactics that are often used by ideologies to encourage and / or justify political violence. The review builds on a socio-psychological framework that identifies important existential and epistemological needs that drive people to become ideological extremists, and discusses the mechanisms by which ideological narratives that promote political violence can meet these needs. The review ends with a discussion of two broad ideology options (religious and conservative) that should be particularly suitable for the implementation of this tactic.

Thus, the discussion on the issues under study only confirmed the need to apply critical methodology and expand the study in several directions.

\section{Conclusions}

The study posed the question: "Is it possible to develop a methodology that will allow stakeholders to analyze data on religious security both within religious communities and outside, and identify potential discrepancies at the system level?"

One of the ways out, we believe, is the development and introduction of a course on religious security, developed by religious scholars, combining legal, educational, cultural and spiritual aspects, and aimed exclusively at preventing the influence of destructive religious groups. 
The project is strictly secular in nature and is intended for use in educational institutions. The advantages of this course are that it can be read in both religious and secular venues. The approbation of this course entitled "Pedagogical support of religious security" took place in the first half of 2019 on the basis of the Institute of Continuing Education of the BSPU named after M. Akmulla. According to a survey conducted in 2019 among teachers of secondary educational schools, $86 \%$ of respondents noted the acute urgency of conducting such a course in the modern educational system.

The consequence of this will be a decrease in the number of young people who have fallen under the influence of destructive cults.

Thus, a course on religious safety can be:

1. a factor that can quickly neutralize the influence of destructive religious groups and become a link with the "spiritual security" project.

2. a real project of state-confessional cooperation in such an urgent matter today as the prevention of religious extremism.

3. to promote confessional stability in the multi-ethnic and multi-confessional region of the Russian Federation.

This analysis leads to the conclusion that there are many points of view on the most diverse aspects of the phenomenon of religious deviation, and there is no unity. The main thing is that there is no single view of the essence, structure, and typology.

According to the authors, many aspects of the study have not been disclosed. For example, future work should explore the role of the Internet in religious education $[14,15]$, and its impact on religious deviation, normative adherence, and individual differences in attachment, which provide a framework for understanding human relationships with God [16].

I would also like to study the problem of systemic control, cultural values and religious institutions in the prism of religious deviation [17].

This state of affairs also raises the question of the need for further study of these problems. Future research work will be focused on participation in these studies.

\section{References}

1. V.P. Branskii, Questions of Philosophy, 4, 112-129 (2000)

2. R.I. Zekrist, Synergistic extension of the method of cultural studies: [monograph]. (LAP LAMBERT Academic Publishing, Germany, 2018)

3. H. Haken, H. Knyazeva, Journal for General Philosophy of Science, 31, 1, 57-73 (2000)

4. T. Fitzgerald, Method \& Theory in the Study of Religion, 15, 21 (2003)

5. R.N. Lunkin, Religion and law [Electronic resource] (2017) http://www.sclj.ru/news/index.php?sphrase_id=171522\&print=Y\&PAGEN_1=13

6. R.N. Lunkin, Policy Memo, 16, 199 (2020)

7. M.M. Mchedlova, E.N. Kofanova, A.G. Shevchenko, Orthodoxy and loyalty: from social tension to the choice between power and church, 12 (2020), DOI: 10.19181/ezheg.2020.12

8. D.A. Uzlaner, The neoclassical model of secularization in Western sociology of religion in the second half of the XX - early XXI centuries: Dis. Candidate Philos. Sciences: 09.00.13 Moscow (2009)

9. E.D. Pavlova, Latent influence of the mass media on mass consciousness as a sociophilosophical problem: Dis. ... Cand. philosophy. Science. - Moscow, (2004) 
10. L. Stapleton, D. Marques, T. Thakar., IFAC-Papers OnLine, 50, 1, 6373-6378 (2017) https://doi.org/10.1016/j.ifacol.2017.08.1028

11. Th. Frissen, Computers in Human Behavior, 114, 106549 (2021) https://doi.org/10.1016/j.chb.2020.106549

12. S. Z. Hamrah, Procedia - Social and Behavioral Sciences, 29, 1740-1749 (2011) https://doi.org/10.1016/j.sbspro.2011.11.420

13. D. Webber, A. Kruglanski, E.Molinario, K. Jasko, Current Opinion in Behavioral Sciences, 34, 107-111 (2020) https://doi.org/10.1016/j.cobeha.2020.01.004

14. S. Z. Hamrah, Procedia - Social and Behavioral Sciences, 29, 1740-1749 (2011) https://doi.org/10.1016/j.sbspro.2011.11.420

15. R. Silva, P. Fernández-Navarro, M. M. Gonçalves, C. Rosa, J. Silva, Aggression and Violent Behavior, 47, 204-214 (2019) https://doi.org/10.1016/j.avb.2019.05.002

16. A. DCherniak, M.Mikulincer, P. RShaver, Current Opinion in Psychology, 40, 126-130 (2021) https://doi.org/10.1016/j.copsyc.2020.08.020

17. L. Stapleton, D. Marques, T. Thakar., IFAC-PapersOnLine, 50, 1, 6373-6378 (2017) https://doi.org/10.1016/j.ifacol.2017.08.1028 